\title{
PERKEMBANGAN REGULASI PRANATA JAMINAN SAHAM TANPA WARKAT (SCRIPLESS) SEBAGAI OBJEK TRANSAKSI DI PASAR MODAL
}

Lastuti Abubakar dan Tri Handayani

Fakultas Hukum Universitas Padjadjaran

J1. Raya Bandung Sumedang KM.21, Hegarmanah, Jatinangor, Kabupaten Sumedang, Jawa

Barat 45363, Telp/Fax: (022) 84288828, e-mail: lastuti62abubakar@gmail.com

\begin{abstract}
Abstrak
Salah satu unsur dalam analisa pemberian kredit atau pembiayaan baik yang disediakan oleh perbankan maupun perusahaan pembiayaan adalah ketersediaan agunan (collateral), khususnya jaminan kebendaan. Saham yang diperdagangkan di pasar modal melalui sistem perdagangan tanpa warkat (scripless trading system) merupakan surat berharga yang dapat dijadikan objek jaminan guna memperoleh kredit atau pembiayaan. Di sisi lain, penjaminan saham tanpa warkat tetap harus patuh pada prinsip kehati-hatian bank (prudential banking principle) dan memperhatikan tujuan perdagangan di Bursa Efek. Permasalahan hukum yang hendak dikaji dan dianalisa dalam tulisan ini adalah pranata jaminan apa yang tepat bagi saham tanpa warkat (scripless) dilihat dari sisi kepentingan kreditur Bank dan sistem perdagangan di pasar modal? Penelitian ini bersifat deskriptif analitis dengan menggunakan pendekatan yuridis normatif, selanjutnya data dianalisis dengan menggunakan analisis data yuridis kualitatif. Berdasarkan penelitian, diperoleh hasil bahwa Gadai merupakan pranata jaminan yang tepat bagi saham tanpa warkat karena selain memberikan perlindungan hukum yang optimal bagi perbankan sebagai kreditur juga mendukun terciptanya perdagangan yang teratur, wajar dan efisien. Penguasaan saham tanpa warkat sebagai objek gadai oleh kreditor sebagai syarat sah nya gadai dapat dipenuhi dengan mendudukkan PT KSEI sebagai pihak ketiga yang disetujui untuk menguasai saham tanpa warkat dalam bentuk data elektronik.
\end{abstract}

Kata kunci : scripless trading system- saham tanpa warkat- gadai saham

\section{A.Pendahuluan}

Perubahan tatanan regulasi di bidang keuangan dan perbankan telah memberikan kesempatan dan kemudahan bagi bank untuk mengembangkan usahanya berdasarkan pada asas perbankan yang sehat. Kegiatan utama usaha Bank adalah melakukan fungsi intermediary, yaitu menghimpun dana dan menyalurkannya dalam bentuk kredit atau pembiayaan. ${ }^{1}$ Dalam menyalurkan kredit atau pembiayaan, Bank wajib mematuhi prinsip kehati-hatian bank (prudential banking principle), yang secara spesifik diatur dalam Pasal 8 dan Penjelasan Pasal 8 Undang-Undang Nomor 10 Tahun 1998 Tentang Perubahan Undang-Undang Nomor 7 Tahun 1992 Tentang Perbankan

\footnotetext{
${ }^{1}$ Istilah pembiayaan digunakan dalam UU No : 21 Tahun 2008 Tentang Perbankan Syariah, untuk menggantikan istilah kredit yang berbasis bunga.
} 
(UU Perbankan). Penjelasan Pasal 8 UU Perbankan menegaskan bahwa Bank wajib memiliki keyakinan bahwa debitor beritikad baik dan mempunyai kemampuan untuk membayar utangnya. Untuk memperoleh keyakinan tersebut, sebelum memberikan kredit atau pembiayaan, bank wajib melakukan analisa pemberian kredit, yang dikenal dengan the 5C's analysis of credit, yang salah satunya adalah collateral (agunan). Selain collateral, bank wajib melakukan analisa terhadap watak (character); kemampuan (capacity); modal (capital); dan prospek usaha dari nasabah debitor (condition of economic). ${ }^{2}$

Salah satu peluang perbankan untuk mengoptimalkan kegiatan usahanya adalah pemberian kredit atau pembiayaan dengan jaminan saham Perseroan Terbatas (PT) yang terdaftar dan diperdagangkan di Bursa Efek Indonesia. ${ }^{3}$ Ini berarti saham yang akan dijaminkan adalah saham yang diperdagangkan melalui sistem perdagangan tanpa warkat (scripless

\footnotetext{
${ }^{2}$ Lihat penjelasan Pasal 8 Ayat (1) UU Perbankan.

3 Pasal 1 Angka 7 UU PT mengatur bahwa Perseroan Terbuka adalah Perseroan Publik atau Perseroan yang melakukan penawaran umum saham sesuai dengan ketentuan peraturan perundang-undangan di pasar modal. Selanjutnya Pasal 1 Angka 22 UU Pasar Modal mengatur bahwa yang dimaksud dengan Perusahaan Publik adalah Perseroan yang sahamnya telah dimiliki sekurang-kurangnya oleh 300 pemegang saham dan memiliki modal disetor sekurang-kurangnya Rp.3.000.000.000,00 (tiga miliar rupiah) atau suatu jumlah pemegang saham dan modal disetor yang ditetapkan dengan Peraturan Pemerintah.
}

trading system). Salah satu karakteristik saham yang diperdagangkan di Bursa Efek adalah harga yang sifatnya fluktuatif sesuai dengan permintaan dan penawaran. Hal ini menjadi salah satu isu strategis penjaminan saham yang diperdagangkan di Bursa Efek sebagai objek jaminan. Isu hukum lainnya adalah ketiadaan fisik saham, sehingga pembuktian kepemilikan dan peralihan saham secara fisik perlu ditafsirkan secara baik untuk memperoleh landasan hukum bagi transaksi saham scripless, khususnya sebagai objek jaminan.

Sejalan dengan perkembangan regulasi di sektor perbankan, saham tanpa warkat (scripless) dapat digunakan untuk memperoleh kredit atau pembiayaan, khususnya bagi para pelaku usaha. Perkembangan regulasi perbankan yang berkaitan dengan jaminan saham ini tidak dapat dilepaskan dari kebutuhan para pelaku usaha untuk memperoleh pembiayaan usaha baik yang difasilitasi oleh perbankan maupun lembaga pembiayaan lainnya.

Bahkan, perjanjian jaminan ini tidak hanya dibutuhkan dalam perjanjian kredit atau pembiayaan, namun diperlukan dalam berbagai hubungan kontraktual, khususnya dalam perjanjian timbal balik yang menempatkan para pihak dalam kedudukan sebagai kreditor dan debitor. 
Oleh karena itu, dalam praktik bisnis ${ }^{4}$, perjanjian jaminan lazim digunakan atau ditemukan dalam kontrak-kontrak bisnis seperti perjanjian ekspor impor, pemborongan, perjanjian leasing, perjanjian BOT (Build,Operate and Transfer) bahkan dalam perjanjian jual beli secara angsuran.

Perjanjian pemborongan misalnya, lazim menggunakan jaminan berupa bank guarantee (garansi bank) yang dikeluarkan oleh bank sebagai salah satu kegiatan usaha Bank yang diatur dalam UU Perbankan. Selanjutnya, mekanisme pemberian garansi bank ini diatur dalam dalam Surat Keputusan Direksi Bank Indonesia Nomor : 23/88/KEP/DIR/1991 Tentang Pemberian Garansi Oleh Bank. Garansi Bank ini merupakan pengembangan dari pranata penanggungan (borgtocht) yang diatur dalam Pasal 18201850 KUHPerdata.

Berbeda dengan penanggungan yang objek jaminannya adalah kesanggupan penanggung untuk membayar apabila debitor tidak mampu membayar, maka

\footnotetext{
4 Bisnis diartikan sebagai keseluruhan kegiatan usaha yang dijalankan oleh orang atau badan secara teratur dan terus menerus, yaitu kegiatan mengadakan barang atau jasa maupun fasilitas untuk diperjualbelikan, dipertukarkan, atau disewakan dengan tujuan mendapatkan keuntungan. Lihat Richard Burton SImatupang dalam Neni Sri Imaniyati \& Panji Adam Agus Putra, Hukum Bisnis -Dilengkapi Dengan Kajian Hukum Bisnis Syariah, Refika Aditama, Bandung, 2017, hlm.3.
}

dalam Bank Garansi tertentu, Bank lazim akan meminta kontra garansi sebagai implementasi prinsip kehati-hatian.

Urgensi akan adanya pranata jaminan dalam kontrak bisnis, khususnya di sektor jasa keuangan ini semakin tampak dengan diterbitkannya UndangUndang Nomor : 1 Tahun 2016 Tentang Penjaminan (UU Penjaminan). Diharapkan dengan adanya Lembaga Penjaminan ini, usaha mikro, kecil, menengah dan koperasi yang selama ini dianggap tidak bankable, akan lebih mudah memperoleh akses permodalan, terutama dari perbankan

Berbeda dengan kontrak bisnis lainnya, regulasi perbankan mewajibkan adanya jaminan dalam pemberian kredit sebagai implementasi dari prinsip kehatihatian bank (prudential banking principle) yang wajib dipatuhi oleh Bank sebelum pemberian kredit atau pembiayaan. Kewajiban ini dapat dilihat dalam Pasal 8 dan penjelasan Pasal 8 UU Perbankan. Pasal 8 mengatur bahwa :

"Dalam memberikan kredit atau pembiayaan berdasarkan prinsip syariah, Bank Umum wajib mempunyai keyakinan berdasarkan analisis yang mendalam atas itikad dan kemampuan serta kesanggupan Nasabah Debitur untuk melunasi utangnya atau mengembalikan pembiayaan dimaksud sesuai dengan yang diperjanjikan". 
Itikad baik dan kesanggupan nasabah untuk melunasi utangnya yang dimaksud dalam Pasal 8 tersebut, lazim ditafsirkan sebagai jaminan dalam konteks ekonomi, yang dianggap belum memberikan perlindungan yang cukup bagi bank sebagai kreditor. Jaminan secara yuridis dapat disimpulkan dari penjelasan Pasal 8 alinea ke dua yang mengatur bahwa “ untuk memperoleh keyakinan tersebut, sebelum memberikan kredit, bank harus melakukan penilaian yang seksama terhadap watak, kemampuan, modal, agunan, dan prospek usaha dari Nasabah Debitor".

Agunan (collateral) inilah yang dimaksud dengan jaminan secara yuridis. Menilik penjelasan Pasal 8 alinea ketiga UU Perbankan,yang mengatur: "mengingat bahwa agunan sebagai salah satu unsur pemberian kredit, maka apabila berdasarkan unsur-unsur lain telah dapat diperoleh keyakinan atas kemampuan nasabah debitur mengembalikan utangnya, agunan hanya berupa barang, proyek, atau hak tagih yang dibiayai dengan kredit yang bersangkutan...”.Merujuk pada penjelasan Pasal 8 di atas, maka agunan yang wajib disediakan oleh debitur adalah agunan pokok saja, sehingga agunan tambahan hanya digunakan sebagai pelengkap saja. Dengan demikian, istilah Kredit Tanpa Agunan (KTA) bukan berarti tidak ada agunan, melainkan cukup dengan agunan pokok berupa objek kreditnya. Kewajiban adanya jaminan dalam pemberian kredit ini merupakan implementasi prudential banking principle sebagai prinsip utama dalam aktivitas perbankan. Prinsip ini secara tegas diatur dalam Pasal 2 UU Perbankan yang mengatur bahwa Perbankan Indonesia dalam melakukan usahanya berasaskan demokrasi ekonomi dengan menggunakan prinsip kehatihatian.

Selain Pasal 2, pelaksanaan prinsip kehati-hatian dapat disimpulkan dari Pasal 8 dan 29 UU Perbankan. Prinsip ini sejalan dengan fungsi Bank sebagai intermediary yaitu menghimpun dana dan menyalurkannya dalam bentuk kredit atau pembiayaan. Dana yang dihimpun dan disalurkan ini adalah dana Pihak Ketiga, sehingga Bank wajib berhati-hati dalam menyalurkan dana Pihak Ketiga. Hal ini untuk menjaga kepercayaan masyarakat terhadap Bank sebagai agent of trust. ${ }^{5}$

Dalam praktik pemberian kredit atau pembiayaan, agunan merupakan salah satu upaya bagi Bank untuk mengamankan dana yang disalurkan. Sama halnya dengan perbankan konvensional, Undang-Undang Nomor : 21 Tahun 2008 Tentang Perbankan Syariah (UU Perbankan

\footnotetext{
${ }^{5}$ Lihat Otoritas Jasa Keuangan,(2016), PerbankanSeri Literasi Perguruan Tinggi- Seri 2, Jakarta, hlm. 6.
} 
Syariah) dalam Pasal 2, 23 dan Pasal 36 mengatur bahwa kegiatan perbankan syariah salah satunya berlandaskan prinsip kehati-hatian. $^{6}$ Selanjutnya, dalam memberikan pembiayaan, Pasal 23 Ayat (2) UU Perbankan Syariah mewajibkan Bank melakukan penilaian yang sama dengan UU Perbankan, yaitu terhadap watak, kemampuan, modal, agunan dan prospek usaha dari calon penerima fasilitas (the 5C's analysis of credit).

Dalam perkembangannya, tatanan hukum jaminan mengalami perubahan sejalan dengan perkembangan hukum ekonomi dan bisnis. Berlakunya jaminan berdasarkan prinsip syariah turut memberikan warna bagi perkembangan hukum jaminan Indonesia. Dapat dikatakan bahwa saat ini telah terjadi dualisme hukum ekonomi, termasuk dualisme hukum jaminan dengan diberlakukannya jaminan berdasarkan prinsip syariah. $^{7}$ Selain berlakunya jaminan berdasarkan prinsip syariah, perkembangan hukum jaminan ditandai dengan diterbitkannya beragam jenis surat berharga dalam praktik bisnis, baik di pasar keuangan maupun pasar modal. Surat berharga di pasar modal mengalami

\footnotetext{
${ }^{6}$ Pasal 2 UU Perbankan Syariah mengatur bahwa "Perbankan syariah dalam melakukan kegiatan usahanya berasaskan Prinsip syariah, demokrasi ekonomi, dan prinsip kehati-hatian.

${ }^{7}$ Dualime hukum adalah berlakunya lebih dari satu sistem hukum yang mengatur bidang yang sama.
}

perubahan bentuk akibat diterapkannya sistem perdagangan tanpa warkat (scripless trading system), yang mekanismenya dilakukan melalui penyelesaian pemindahbukuan (book-entry settlement), sehingga tidak ada fisik efek atau uang yang ditransaksikan.

Penyelesaian pemindahbukuan dalam sistem perdagangan tanpa warkat ini diberlakukan sejak pertengahan tahun 2000, dan seluruh efek , khususnya saham yang diperdagangkan di Bursa Efek Indonesia sudah dikonversikan dari bentuk fisik menjadi bentuk elektronik. ${ }^{8}$ Dengan demikian, terdapat perubahan bentuk efek termasuk saham yang diperdagangkan melalui sistem perdagangan tanpa warkat ini, dari yang semula berbentuk fisik menjadi bentuk elektronik yang disimpan di PT Kustodian Sentral Efek Indonesia (PT KSEI) sebagai Lembaga Penyimpanan dan Penyelesaian (LPP).

Perkembangan regulasi saham tanpa warkat (scripless) sebagai objek jaminan dalam perjanjian kredit atau pembiayaan ini membuka peluang bagi perbankan untuk meningkatkan usahanya. Selain bagi bank, jaminan saham tanpa warkat sebagai jaminan kredit akan berkontribusi positif pada perkembangan pasar modal

\footnotetext{
${ }^{8}$ Lastuti Abubakar,(2009), Transaksi Derivatif Di Indonesia-Tinjauan Hukum Tentang Perdagangan Derivatif Di Bursa Efek, Books Terrace \& Library, hlm. 9.
} 
Indonesia. Mengingat saham tanpa warkat termasuk ke dalam klasififikasi benda bergerak tidak berwujud, maka terdapat 2 pranata jaminan yang dapat digunakan bagi saham tanpa warkat ini.

Pertama, saham tanpa warkat dapat dijaminkan dengan menggunakan pranata gadai. Pasal 1150 KUHPerdata mengatur bahwa gadai adalah " suatu hak yang diperoleh seorang berpiutang (kreditur) atas suatu barang bergerak...dst". Pengaturan dalam Pasal 1150 KUHPerdata ini tidak secara eksplisit menyebutkan jenis barang, sehingga dapat diartikan bahwa yang dimaksudkan dengan barang bergerak adalah semua barang baik berwujud maupun tidak berwujud.

Selain gadai, saham tanpa warkat dapat dijaminkan dengan menggunakan Fidusia. Pasal 2 Undang-Undang Nomor : 42 Tahun 1999 Tentang Fidusia (UU Fidusia) mengatur bahwa benda objek fidusia adalah segala sesuatu yang dapat dimiliki, baik yang bewujud maupun yang tidak berwujud, yang terdaftar maupun yang tidak terdaftar, yang bergerak maupun yang tidak bergerak yang tidak dapat dibebani hak tanggungan atau hipotek". Dengan demikian, terdapat dua pranata jaminan yang dapat digunakan untuk penjaminan saham tanpa warkat, yaitu gadai dan fidusia. Dalam praktik, opsi pranata jaminan yang tepat bagi saham tanpa warkat tidak dapat dilepaskan dari kebutuhan pasar modal, khususnya tujuan transaksi di Bursa Efek untuk menciptakan perdagangan yang wajar, teratur dan efisien serta prinsip kehatihatian bank.

Berdasarkan latar belakang yang telah diuraikan, maka permasalahan hukum yang hendak dikaji dan dianalisa dalam tulisan ini adalah pranata jaminan apa yang tepat bagi saham tanpa warkat (scripless) dilihat dari sisi kepentingan kreditur Bank dan sistem perdagangan di pasar modal?

\section{B. Metode Penelitian}

Spesifikasi Penelitian

Penelitian bersifat deskriptif analitis, yaitu membuat pencandraan secara sistematis, faktual dan akurat mengani fakta-fakta. ${ }^{9}$ Oleh karena itu, penelitian ini sifatnya menggambarkan hasil analisa data yang diperoleh berupa data sekunder yang terdiri dari bahan hukum primer, sekunder dan tersier mengenai permasalahan yang akan dikaji yaitu pranata jaminan apa yang tepat bagi saham tanpa warkat (scripless) dilihat dari sisi kepentingan kreditur Bank dan sistem perdagangan di pasar modal.

Metode Penelitian

\footnotetext{
${ }^{9}$ Soerjono Soekanto dan Sri Mamudji,(2006), Penelitian Hukum Normatif Suatu Tinjauan Singkat, Rajawali, Jakarta,hlm. 13-14 
Sesuai dengan bidang kajian Ilmu Hukum, pendekatan yang dipakai dalam penelitian ini adalah yuridis normatif, yang lebih menitikberatkan pada studi kepustakaan dan data sekunder melalui proses analisis dengan menggunakan peraturan hukum, serta asas hukum melalui cara menarik asas hukum ${ }^{10}$ untuk mengkaji pranata jaminan bagi saham tanpa warkat (scripless) yang tepat untuk menunjang tujuan menciptakan system perdagangan yang teratur, wajar, dan efisien tanpa mengabaikan prinsip kehatihatian bank (prudential banking principle). Penelitian ini didukung pula oleh metode sejarah hukum, perbandingan hukum dan penafsiran hukum.

Metode Analisa Data

Analisis data yang digunakan di dalam penelitian ini adalah analisis data yuridis kualitatif dengan menggunakan daya abstraksi dan penafsiran hukum (interpretasi), untuk selanjutnya dituangkan dalam bentuk uraian-uraian (deskripsi).

\section{Pembahasan}

Sistem Perdagangan Tanpa Warkat di Bursa Efek Indonesia

Pasar Modal Indonesia sebagai bagian dari sektor jasa keuangan

\footnotetext{
${ }^{10}$ Sri Mamudji, (2005), Metode Penelitian Dan Penulisan Hukum Normatif Suatu Tinjauan Singkat, Rajawali, Jakarta,hlm.13-14.
}

merupakan alternatif pembiayaan dan investasi yang pertumbuhannya meningkat dari waktu ke waktu. Laporan Kinerja OJK 2012-2017 memperlihatkan bahwa jumlah Emiten meningkat 16,78 \% dari 459 emiten pada tahun 2012 menjadi 536 emiten pada triwulan I tahun 2017.

Sementara jumlah investor saham mengalami peningkatan 100,8 \% dari 281,25 ribu investor menjadi 535,99 ribu investor. ${ }^{11}$ Pertumbuhan pasar modal Indonesia ini disebabkan semakin tingginya kepercayaan masyarakat baik nasional, regional dan global pada industri pasar modal di Indonesia. ${ }^{12}$

Banyak faktor yang mempengaruhi pertumbuhan pasar modal antara lain meningkatnya peran sektor swasta dalam berbagai aktivitas ekonomi, perkembangan teknologi, dan akses yang cepat dan mudah untuk mendapatkan informasi keuangan. ${ }^{13}$ Hal ini merupakan dampak

11 Otoritas Jasa Keuangan, Laporan Kinerja Otoritas Jasa Keuangan 2012-2017 (Tanpa Tahun), Jakarta, hlm.2.

12 Berdasarkan Statistik Pasar Modal 2017, komposisi kepemilikan asing yang tercatat di PT KSEI oleh asing sebesar 68,78\% (baik oleh korporasi, perusahaan sekuritas, asuransi dan lembaga lainnya. Lihat Statistik Pasar modal 2017, Otoritas Jasa Keuangan, hlm. 13, https://www.ojk.go.id/id/kanal/pasar-modal/datadan-statistik/statistik-pasar-

modal/Documents/Statistik\%20Desember\%20Mgg \%20ke-4\%202017.pdf, diunduh pada tanggal 29 April 2018,pkl.12.42.

${ }^{13}$ Najeb MH Masoud, (2013), The Impact of Stock Market Performance Upon Economic Growth, International Journal of Economic and Financial Issues, Vol.3, No.4, hlm. 797, 
dari globalisasi yang menjadikan dunia menjadi tanpa batas (borderless world), yang memungkinkan pergerakan barang, jasa dan modal bergerak sedemikian cepat dari satu negara ke negara lain. Globalisasi ekonomi ditandai dengan makin menipisnya batas-batas investasi atau pasar baik secara nasional, regional maupun internasional yang disebabkan oleh $:^{14}$

a. komunikasi dan transportasi yang semakin canggih;

b. lalu lintas devisa yang semakin bebas;

c. ekonomi negara yang makin terbuka;

d. penggunaan secara penuh keunggulan komparatif dan keunggulan kompetitif tiap-tiap negara;

e. metode produksi dan perakitan dengan organisasi manajemen yang semakin efisien;

f. semakin pesatnya perkembangan perusahaan multinasional di hampir seantero dunia.

Globalisasi membuka peluang bagi pasar modal Indonesia untuk menarik portofolio investasi dari berbagai Negara.

Selain itu, perkembangan pasar modal tidak dapat dilepaskan dari perkembangan regulasi dan pedoman dari organisasi pasar

https://www.econjournals.com/index.php/ijefi/articl e/viewFile/557/pdf

14 Hendra Halwani dalam Herlan Firmansyah \& Endang Hendra,(2015), Implikasi Globalisasi Ekonomi Dan Perdagangan Bebas terhadap Stabilitas Nilai Rupiah, Jurnal Asy-Syariah Vol. tujuh belas No.1 hlm. 46 . modal dunia seperti International Organization of Securities Commission (IOSCO), termasuk implementasi sistem perdagangan tanpa warkat (scripless trading system) yang bertujuan untuk menciptakan perdagangan yang wajar, efektif dan efisien dan yang mengurangi risiko sistemik. $^{15}$

Sistem perdagangan tanpa warkat (scripless trading system)yang direkomendasikan oleh IOSCO ini sudah diakomodasikan dalam Pasal 55 Ayat (1) Undang-Undang Nomor : 8 Tahun 1995 Tentang Pasar Modal (UU Pasar Modal) yang mengatur bahwa “ Penyelesaian Transaksi Bursa dapat dilaksanakan dengan penyelesaian pembukuan, penyelesaian fisik, atau cara lain yang ditetapkan dengan Peraturan Pemerintah (PP). ${ }^{16}$ Selanjutnya penjelasan Pasal 55 Ayat (1) menjelaskan bahwa yang dimaksud dengan "penyelesaian pemindahbukuan" (book entry settlement) dalam ayat ini adalah pemenuhan hak dan kewajiban yang timbul sebagai akibat

15 IOSCO, (2017), Objectives and Principles of Securities Principle (Resolution2/2017). hlm. 266, https://www.iosco.org/library/resolutions/pdf/IOSC ORES63.pdf, diunduh pada Rabu 4 April 2018,pkl 6.10 .

${ }^{16}$ Peraturan Pemerintah yang dimaksud adalah PP Nomor : 45 Tahun 1995 Tentang Penyelenggaraan Kegiatan di Bidang Pasar Modal mengatur “" Ketentuan lebih lanjut yang diperlukan bagi penyelenggaraan kegiatan Lembaga Kliring dan Penjaminan atau Lembaga Penyimpanan dan Penyelesaian berdasarkan Peraturan ini, ditetapkan oleh Bapepam. 
adanya Transaksi Bursa yang dilaksanakan dengan cara mengurangi efek dari rekening efek yang satu dan menambahkan efek dimaksud pada rekening efek yang lain pada Kustodian, yang dalam hal ini dapat dilakukan secara elektronik.

Esensi dari sistem perdagangan tanpa warkat ini adalah tidak ada peralihan efek secara fisik (immobilisasi efek), sehingga peran PT KSEI sangat besar sebagai lembaga penyimpanan dan penyelesaia. ${ }^{17}$ Selain PT KSEI, mekanisme transaksi di Bursa Efek Indonesia melibatkan 2 SRO ( Self Regulatory Organization) lainnya, yaitu Bursa Efek dan Lembaga Kliring dan Penjaminan (LKP).

Lembaga Kliring dan Penjaminan didirikan dengan tujuan menyediakan jasa kliring dan penjaminan penyelesaian transaksi Bursa. ${ }^{18}$ Fungsi penjaminan oleh LKP ini diyakini mampu meningkatkan intensitas transaksi tanpa risiko gagal bayar dan gagal serah dengan mendudukkan PT KPEI sebagai mitra pengimbang (counter party) yang akan menjamin penyelesaian transaksi bursa. ${ }^{19}$

\footnotetext{
${ }^{17}$ Lastuti Abubakar, Op.Cit, hlm. 242.

18 Kliring adalah proses penentuan hak dan kewajiban para pihak dalam Transaksi Bursa.

19 Risiko gagal serah dan gagal bayar dalam transaksi Bursa diantisipasi oleh LKP sebagai mitra pengimbang yang mengambil alih kewajiban masing-masing pihak, baik kewajiban serah maupun kewajiban bayar. Lihat Peraturan OJK No:
}

Hal ini sejalan dengan tujuan Bursa Efek sebagaimana diatur dalam Pasal 7 UU Pasar Modal bahwa Bursa Efek didirikan untuk menyelenggarakan perdagangan efek yang teratur, wajar dan efisien. Selanjutnya, penjelasan Pasal 7 memaknai perdagangan efek secara teratur, wajar, dan efisien adalah suatu perdagangan yang diselenggarakan berdasarkan suatu aturan yang jelas dan dilaksanakan secara konsisten. Dengan demikian, harga yang terjadi mencerminkan mekanisme pasar berdasarkan kekuatan permintaan dan penawaran. Perdagangan efek yang efisien tercermin dalam penyelesaian transaksi yang cepat dengan biaya yang relatif murah.

Sistem perdagangan tanpa warkat (scripless trading system) yang direkomendasikan oleh IOSCO diharapkan dapat memenuhi kriteria tersebut. Secara umum keuntungan sistem perdagangan tanpa warkat antara lain biaya transaksi yang rendah, praktis, tidak ada risiko pemalsuan atau kehilangan serta berkurangnya kegagalan dalam penyelesaian transaksi. Secara terperinci beberapa manfaat sistem perdagangan tanpa warkat adalah sebagai berikut : ${ }^{20}$

26/POJK.04/2014 Tentang Penjaminan Penyelesaian Transaksi Bursa.

${ }^{20}$ Lastuti Abubakar, Op. Cit, hlm.238. 
a. tidak membutuhkan proses registrasi karena pemindahan hak dilakukan dengan pemindahbukuan (book entry settlement);

b. tidak memerlukan pencetakan efek dan meterai;

c. mengurangi risiko kerugian akibat efek hilang, rusak atau palsu;

d. tidak memerlukan ruang penyimpanan (vault) untuk menyimpan efek di kantor investor, Bank Kustodian atau Anggota Bursa (Perusahaan Efek);

e. proses penyelesaian transaksi yang sederhana dan cepat sehingga menungkinkan penyelsaian transaksi dalam volume besar dan tepat waktu;

f. informasi status penyelesaian lebih lengkap, tepat, dan akurat.

Dengan demikian, sistem perdagangan tanpa warkat merupakan sistem perdagangan yang sesuai dengan standar internasional. Kepatuhan terhadap standar internasional ini menjadi relevan, mengingat di era global dan pemanfaatan teknologi informasi dalam transaksi bisnis dan perdagangan, pasar modal Indonesia berpeluang menjadi alternatif investasi yang menarik bagi pemilik modal di seluruh dunia. Hal ini sejalan dengan sifat modal, yang akan mengalir ke tempat yang akan mendatangkan return (keuntungan) paling optimal, sepanjang investor memperoleh perlindungan dan kepastian hukum atas investasinya. Itu sebabnya, sebagai bagian dari pasar modal global, kepastian dan perlindungan hukum melalui implementasi sistem perdagangan tanpa warkat ini menjadi bagian dari regulasi di Pasar Modal.

Saham Tanpa Warkat Sebagai Objek Jaminan

Pasar modal merupakan salah satu sektor jasa keuangan yang banyak mengembangkan instrumen efek atau surat berharga sebagai objek transaksi. Pasal 1 Angka 5 UU Pasar Modal mengatur bahwa yang dimaksud dengan efek adalah " surat berharga, yaitu surat pengakuan utang, surat berharga komersial, saham, obligasi, tanda bukti utang, Unit Penyertaan Kontrak Investasi Kolektif, Kontrak Berjangka Atas Efek, dan setiap derivatif dari efek".

Instrumen derivatif inilah yang selanjutnya banyak dikembangkan di pasar modal Indonesia. Berdasarkan penjelasan Pasal 1 Angka 5 memberikan penjelasan bahwa "yang dimaksud dengan derivatif dari efek adalah turunan dari Efek, baik efek yang bersifat utang maupun yang bersifat ekuitas, seperti opsi dan waran”. Peraturan di pasar modal tidak memberikan pengertian secara yuridis apa yang dimaksud dengan derivatif. Oleh karena itu, perlu dilihat beberapa 
pengertian derivatif dalam beberapa literatur.

Corpus Juris Secundum mengartikan derivatif sebagai " $a$ noun, that which is derived, anything obtained or deduced from another. Sama dengan pengertian tersebut, Black's Law Dictionary mengartikan derivatif sebagai "coming from another; take from something preceding; secondary. That which has not its origin in itself, but owes its existence to something foregoing. Berdasarkan definisi- definisi tersebut dapat disimpulkan bahwa instrumen derivatif adalah instrumen yang eksistensinya bergantung pada instrumen lain atau diturunkan dari instrumen lain. ${ }^{21}$

Dilihat dari definisi efek berdasarkan Pasal 1 Angka 5 UU Pasar Modal, maka efek atau surat berharga yang diperdagangkan di pasar modal dapat dikelompokkan menjadi 3 jenis yaitu : surat berharga pengakuan utang (debt instrument), surat berharga bersifat penyertaan (equity instrument) dan derivatif dari ke dua instrumen tersebut. Dalam perkembangannya, pasar modal menyediakan beragam instrumen derivatif, baik yang diturunkan dari efek bersifat utang (debt instrument) seperti obligasi konversi (convertible bond) maupun dari instrumen penyertaan (equity instrument),

\footnotetext{
${ }^{21}$ Lastuti Abubakar, Op.Cit, hlm. 11.
}

seperti bukti right (right issue), Kontrak Berjangka Indeks Efek (KBIE /LQ 45 Futures) dan Kontrak Opsi Saham.

Namun demikian, surat berharga yang paling banya diperdagangkan di pasar modal Indonesia adalah saham. Berdasarkan laporan pasar modal 2017, saham termasuk efek yang paling banyak ditransaksikan di Bursa Efek Indonesia, yaitu sebesar 12.240.53 juta. ${ }^{22}$ Banyaknya saham yang ditransaksikan ini berpotensi dimanfaatkan sebagai objek jaminan untuk memperoleh pembiayaan.

Sebagai benda bergerak tidak berwujud, saham tanpa warkat memiliki sifat-sifat kebendaan yaitu : ${ }^{23}$

a. bersifat absolut, yaitu dapat dipertahankan terhadap siapapun juga.

b. memiliki droit de suite (zaakgevolg), artinya hak itu terus mengikuti bendanya di tangan siapapun juga benda itu berada, dan hak itu akan mengikuti orang yang memilikinya. Tidak demikian halnya dengan hak perorangan, yang dapat dipertahankan terhadap seseorang

c. memiliki droit de preference, yaitu hak untuk didahulukan daripada kreditur lainnya (kreditur konkuren).

22 Otoritas Jasa Keuangan, Statistik Pasar Modal 2017, hlm.i.

${ }^{23}$ Sri Soedewi Maschoen Sofwan, (2000), Hukum Perdata : Hukum Benda, Liberty, Yogyakarta, hlm.12. 
d. Selain sifat di atas, tingkatan hak kebendaan didasarkan pada terjadinya hak, oleh karena itu hak yang lahir terlebih dahulu lebih tinggi kedudukannya daripada hak yang lahir kemudian.

Selain sifat-sifat kebendaan di atas, pemilik atas hak kebendaan yang secara jujur (te goede trouw) atas barang-barang bergerak dilindungi oleh hukum. Hal ini dapat dilihat dalam Pasal 1977 KUHPerdata, yang mengatur bahwa bezitter atas benda-benda bergerak dilindungi.

Buku II KUHPerdata Tentang Benda mengatur beberapa hak kebendaan, yang dapat dibedakan menjadi hak kebendaan yang bersifat memberi kenikmatan yang dapat berasal dari benda miliknya sendiri (hak milik) atau benda milik orang lain (bezitter) dan hak kebendaan yang bersifat memberikan jaminan. Saat ini terdapat beberapa hak kebendaan yang bersifat memberikan jaminan yaitu gadai dan hipotik yang diatur dalam Buku II KUHPerdata, Hak Tanggungan yang diatur dalam Undang-Undang Nomor: 4 Tahun 1996 dan Fidusia yang diatur dalam Undang-Undang Nomor : 42 Tahun 1999.

Saham merupakan representasi dari modal Perseroan Terbatas, yang tunduk pada Undang-Undang Nomor : 40 Tahun 2007 Tentang Perseroan Terbatas ( UU
PT) sebagai lex generalis. Selanjutnya, saham yang diperdagangkan di pasar modal tunduk pula pada UU Pasar Modal sebagai lex specialis. ${ }^{24}$

Berdasarkan Pasal 51 UU PT, pemegang saham diberi bukti pemilikan saham yang dimiliki. Selanjutnya penjelasan Pasal 51 mengatur bahwa pengaturan bentuk pemilikan saham ditetapkan dalam anggaran dasar sesuai dengan kebutuhan. Pengaturan ini sedikit berbeda dengan pengaturan tentang bukti pemilikan saham yang diatur dalam Pasal 44 UU No: 1 Tahun 1995 Tentang Perseroan Terbatas yang sudah dicabut.

Berdasarkan Pasal 44 dan penjelasan Pasal 44 tersebut, bukti pemilikan saham atas tunjuk berupa surat saham, sedangkan bukti pemilikan saham atas nama diserahkan kepada para pihak dan ditetapkan dalam Anggaran Dasar. Hal ini berarti, bukti pemilikan saham berdasarkan UU No : 1 Tahun 1995 masih menggunakan bukti fisik berupa surat (warkat) atau sertifikat saham.

Pengaturan bukti pemilikan saham berdasarkan UU No : 40 Tahun 2007 tampaknya sudah mengakomodasikan perkembangan bentuk saham yang

\footnotetext{
24 Berlaku asas lex specialis derogate legi generalis. Dalam hal UU Pasar Modal sudah mengatur maka UU PT tidak berlaku, dan sebaliknya apabila UU Pasar Modal tidak mengatur maka UU PT berlaku.
} 
diperdagangkan di Bursa Efek yang tidak lagi berbentuk sertifikat atau warkat (scripless). Oleh karena itu, terbuka untuk menggunakan bukti saham berupa bukti selain bukti warkat atau sertifikat. Mengingat saham yang diperdagangkan di Bursa Efek telah dikonversi atau diubah ke dalam bentuk data elektronik, maka bukti pemilikan saham yang diperdagangkan di Bursa Efek adalah berupa data elektronik yang disimpan di PT KSEI.

Penerimaan data elektronik sebagai dokumen hukum dan alat bukti mempunyai landasan hukum yaitu Undang-Undang Nomor : 11 Tahun 2008 Tentang Informasi dan Transaksi Elektronik (UU ITE). Pasal 5 Ayat (1) UU ITE mengatur bahwa " informasi dan/atau dokumen elektronik dan /atau hasil cetaknya merupakan alat bukti hukum yang sah". Selanjutnya, Pasal 5 Ayat (2) mengatur bahwa informasi elektronik dan/atau dokumen elektronik merupakan perluasan alat bukti yang sah sesuai dengan hukum acara yang berlaku di Indonesia. Dengan demikian, tidak ada keraguan perihal bukti pemilikan saham yang diperdagangkan melalui perdagangan tanpa warkat. Sebelum diundangkannya UU ITE, penerimaan data elektronik diatur dalam peraturan yang dibuat oleh Bursa Efek, sehingga dianggap belum memperoleh landasan hukum yang kokoh.
Mengingat sistem perdagangan tanpa warkat (scripless trading system) merupakan amanat UU Pasar Modal, dapat ditafsirkan bahwa pengaturan oleh Bursa Efek selaku SRO dapat diterima sebagai pengaturan khusus di bidang pasar modal, namun tidak dapat digunakan sebagai landasan hukum umum.

Selain diterbitkan tanpa warkat, saham yang diperdagangkan melalui sripless trading system ini menimbulkan beberapa akibat hukum. Pertama, PT KSEI akan bertindak sebagai pemilik terdaftar (registered owner) atas seluruh efek dalam penitipan kolektif untuk kepentingan pemilik efek sebagai beneficial owner.

Sekilas tampak bahwa penitipan kolektif pada PT KSEI ini mengadaptasi konsep dual ownership yang dikenal dalam sistem common law. Penulis berpendapat bahwa konsep dual ownership dalam penitipan kolektif hanya untuk memudahkan mekanisme penyimpanan dan penyelesaian transaksi. Akibat hukum lainnya adalah terjadi kesepadanan efek ( fungibility of shares) atas saham yang disimpan dalam penitipan kolektif. Konsep kesepadan efek (fungibility of shares) ini diatur dalam Pasal 57 UU Pasar Modal bahwa " dalam penitipan kolektif efek dari jenis dan klasifikasi yang sama yang diterbitkan oleh emiten tertentu dianggap sepadan dan dapat dipertukarkan satu dan 
yang lain". Konsep kesepadanan ini memudahkan peralihan atau perbuatan hukum lainnya atas efek dalam penitipan kolektif, termasuk apabila efek dalam penitipan kolektif tersebut akan diagunkan.

Perbandingan Pengaturan antara Gadai dan Fidusia Saham Tanpa Warkat

a. Pengaturan Gadai Saham Tanpa Warkat Sebagaimana telah diuraikan sebelumnya, saham tanpa warkat merupakan saham dalam bentuk elektronik, yang dapat digunakan sebagai objek jaminan untuk memperoleh pembiayaan atau kredit perbankan. Berdasarkan sistem hukum benda Indonesia , saham tanpa warkat adalah benda bergerak tidak berwujud, yang dapat dijadikan objek gadai yang diatur dalam Pasal 1150-1160 KUHPerdata. Selain itu, saham tanpa warkat dapat pula dijaminkan dengan fidusia. Kekhawatiran gadai saham tanpa warkat hanya karena ketiadaan fisik saham dan penguasaan saham dalam bentuk data elektronik oleh PT KSEI bukanlah kendala bagi saham tanpa warkat untuk menjadi objek gadai, sepanjang syarat sahnya gadai berdasarkan ketentuan gadai di dalam Pasal 1152 Ayat (1) dan (2) dapat dipenuhi.

Pasal 1152 Ayat (1) mengatur bahwa :" hak gadai atas benda-benda bergerak dan atas piutang-piutang bawa diletakkan dengan membawa barangnya gadai di bawah kekuasaan si berpiutang atau seorang pihak ketiga, tentang siapa telah disetujui oleh kedua belah pihak".

$$
\text { Selanjutnya, Pasal } 1152 \text { Ayat (2) }
$$

mengatur tentang syarat sahnya gadai yaitu : “ Tak sah gadai atas segala benda yang dibiarkan tetap dalam kekuasaan si berutang atau si pemberi gadai atau si pemberi gadai, ataupun yang kembali atas kemauan si berpiutang”.

Pasal 1152 Ayat (1) dan (2) di atas mengatur tentang syarat sahnya gadai yaitu penguasaan objek gadai oleh kreditor atau pihak ketiga yang disetujui oleh ke dua belah pihak. Bahkan Pasal 1152 Ayat (2) menegaskan, sekalipun atas kemauan kreditor untuk menyerahkan kembali objek gadai kepada debitor, maka gadai menjadi tidak sah. Keabsahan gadai ini akan menimbulkan akibat hukum yang diatur dalam Pasal 1150 KUHPerdata tentang definisi gadai, yaitu:

“ gadai adalah suatu hak yang diperoleh seorang berpiutang atas suatu benda bergerak,yang diserahkan kepadanya oleh seorang berutang atau oleh seorang lain atas namanya, dan yang memberikan kekuasaan kepada si berpiutang itu untuk mengambil pelunasan dari barang tersebut secara didahulukan daripada orang-orang berpiutang lainnya; dengan kekecualian 
biaya untuk melelang barang tersebut dan biaya yang telah dikeluarkan untuk menyelamatkannya setelah barang itu digadaikan, biaya-biaya mana harus didahulukan".

Mengacu pada beberapa Pasal di atas, maka dapat disimpulkan beberapa unsur-unsur gadai yaitu :

1. Gadai adalah hak kreditor atas benda bergerak;

2. Benda bergerak sebagai objek gadai wajib diserahkan dan dikuasai oleh kreditor atau pihak ketiga yang disetujui oleh kreditor dan debitor.

3. Kreditor mempunyai hak untuk mengambil pelunasan piutangnya dari objek gadai tersebut.

Berdasarkan penafsiran terhadap beberapa pasal dalam ketentuan gadai, gadai saham tanpa warkat memenuhi syarat sahnya gadai dengan merujuk pada Pasal 1152 Ayat (1) KUHPerdata, bahwa objek gadai wajib berada dalam penguasaan kreditor atau pihak ketiga yang disetujui oleh para pihak. Dalam hal ini saham tanpa warkat dalam bentuk data elektronik disimpan (dikuasai) oleh PT KSEI sebagai pihak ketiga.

Dengan demikian, tidak ada kendala bagi penjaminan saham tanpa warkat dengan menggunakan pranata gadai. Mekanisme gadai saham tanpa warkat dilakukan dengan memblokir saham dan memindahkannya ke sub rekening penjaminan saham di PT KSEI sebagaimana diatur dalam Peraturan KSEI Nomor : I-C Tentang Sub Rekening Efek (Lampiran Surat Keputusan Direksi KSEI No. Kep 0029?DIR/KSEI/2017 Tanggal 22 Desember 2017).

Dalam hal debitor wanprestasi atau tidak dapat lagi melakukan kewajibannya, maka eksekusi gadai saham tanpa warkat dilakukan dengan cara melepaskan kembali ke Bursa Efek untuk ditransaksikan berdasarkan harga di Bursa Efek. Harga saham di Bursa Efek mengikuti hukum permintaan dan penawaran, yaitu apabila permintaan banyak maka saham cenderung naik dan sebaliknya harga akan turun apabila permintaan berkurang.

Antisipasi terhadap harga saham di Bursa berfluktuasi diatasi dengan pembatasan nilai kredit yang dapat diberikan terhadap agunan saham. Dalam praktik Bank menerima jaminan gadai saham sebagai jaminan tambahan. Nilai jaminan saham dihitung tidak senilai harga saham saat itu, tetapi $50 \%$ dari harga saham saat itu. Hal ini untuk menghindari fluktuasi harga saham yang diperdagangkan di Bursa dan memenuhi prinsip kehati-hatian bank. 
b. Pengaturan Fidusia Saham Tanpa Warkat

Selain menggunakan pranata gadai, UU Fidusia memungkinkan saham tanpa warkat dapat difidusiakan. Fidusia saham justru tidak mensyaratkan penyerahan atau penguasaan objek jaminan kepada kreditor atau pihak ketiga, namun tetap berada dalam penguasaan debitor dan dapat dimanfaatkan oleh debitor. Pengertian dapat dimanfaatkan disini dapat ditafsirkan bahwa saham tanpa warkat yang diperdagangkan di Bursa Efek, dapat tetap diperjualbelikan. Penulis berpendapat. Fidusia saham ini dianggap kurang memberikan perlindungan yang optimal kepada kreditor pemegang jaminan apabila saham tetap dapat dimanfaatkan dan dalam penguasaan debitor, mengingat pemanfaatan saham tanpa warkat berarti saham masih dapat diperjualbelikan di Bursa Efek. Penulis berpendapat bahwa fidusia saham dapat dianalogikan dengan fidusia barang dalam perdagangan, sehingga debitor wajib menyediakan saham tanpa warkat. Dengan demikian, berlakulah ketentuan dalam Pasal 21 Ayat (1) jo Ayat (3) UU Fidusia. Pasal 21 Ayat (1) mengatur bahwa "pemberi fidusia dapat mengalihkan benda persediaan yang mejadi objek jaminan fidusia dengan cara dan prosedur yang lazim dilakukan dalam usaha perdagangan”. Dalam hal fidusia saham tanpa warkat, maka cara dan prosedur yang lazim tersebut dapat dimaknai sesuai dengan tatacara transaksi di Bursa Efek, yaitu melalui lelang berkesinambungan ( continuous auction market) di pasar reguler $^{25}$ sebagaimana diatur dalam Peraturan No: II-A tentang Perdagangan Efek Bersifat Ekuitas. $^{26}$ Berbeda dengan gadai saham yang syarat sahnya ditentukan oleh penguasaan objek gadai, Undang-Undang Fidusia justru mengatur sebaliknya, yaitu objek fidusia dalam penguasaan debitor. Berkenaan dengan syarat sah nya Fidusia sebagai jaminan kebendaan diatur dalam Pasal 14 Ayat (3) UU Fidusia, yaitu " Jaminan Fidusia lahir pada tanggal yang sama dengan tanggal dicatatnya jaminan Fidusia dalam Buku Daftar Fidusia”. Ketentuan Pasal 14 Ayat (3) ini tidak mengurangi berlakunya Pasal 613 KUHPerdata bagi pengalihan piutang dan kebendaan tidak berwujud lainnya.

Berdasarkan ke dua pranata jaminan yang dapat digunakan untuk

\footnotetext{
25 Pasar dimana perdagangan efek di Bursa dilaksanakan berdasarkan proses tawar menawar secara lelang yang berkesinambungan (continuous auction market) oleh Anggota Bursa Efek dan penyelesaiannya dilakukan pada Hari Bursa Ke-3 setelah terjadinya Transaksi Bursa $(\mathrm{T}+3)$ ( Huruf I.29 Peraturan BNo. II-A Tentang Perdagangan Efek Bersifat Ekuitas.

26 Lampiran Keputusan Direksi Bursa Efek Indonesia No :Kep-00399/BEI/11-2012 yang diubah dengan Keputusan Direksi PT Bursa Efek Indonesia No : Kep-00071/BEI/11-2013 yang diberlakukan pada 6 Januari 2014.
} 
penjaminan saham tanpa warkat, tampak masing-masing memiliki kekuatan dan kelemahan. Gadai saham tanpa warkat memberikan perlindungan hukum yang lebih kuat dibandingkan dengan Fidusia saham, karena objek jaminan berada dalam sub rekening jaminan, yang berada dalam sistem PT KSEI sebagai lembaga Penyimpanan dan Penyelesaian, sehingga saham tidak dapat diperdagangkan. Sedangkan Fidusia saham tanpa warkat, memungkinkan debitor memanfaatkan sahamnya dengan tetap memperdagangkannya di pasar modal, sehingga dianggap berpotensi menimbulkan kendala dalam melakukan eksekusi hak-hak kreditor.

Selain itu, gadai saham tanpa warkat tidak perlu didaftarkan, sehingga tidak ada biaya pendaftaran, sedangkan fidusia saham wajib didaftarkan sebagai syarat untuk lahirnya fidusia dan menimbulkan hak kebendaan bagi kreditor.

Pembebanan biaya pendaftaran lazimnya dibebankan pada debitor, dan ini membuat jaminan fidusia saham akan menjadi lebih mahal dibandingkan gadai saham. Pemilihan pranata jaminan saham tanpa warkat, tidak hanya mempertimbangkan kepentingan kreditor semata, melainkan harus dapat mendorong pertumbuhan pasar modal dengan menciptakan transaksi yang wajar, teratur dan efisien.

Pranata Gadai Saham Tanpa Warkat dalam Praktik Pasar Modal

Praktik penjaminan saham tanpa warkat di Bursa Efek Indonesia menggunakan gadai sebagai pranata jaminan yang dianggap lebih tepat untuk memenuhi prinsip-prinsip pasar modal. Terdapat beberapa alasan mengapa gadai saham tanpa warkat lebih tepat dibandingkan fidusia. Alasan utama berkaitan erat dengan prinsip perdagangan di Bursa Efek yaitu terutama untuk menciptakan pasar yang teratur, wajar dan efisien berdasarkan Pasal 7 UU Pasar Modal. Berikut beberapa keunggulan gadai saham tanpa warkat apabila dibandingkan dengan fidusia.

Tabel 1. Gadai Saham Tanpa Warkat

\begin{tabular}{|l|l|l|l|l|}
\hline No & Ukuran & Gadai & Fidusia & Keterangan \\
\hline
\end{tabular}




\begin{tabular}{|c|c|c|c|c|}
\hline 1 & Kepentingan kreditor & $\mathrm{v}$ & $\mathrm{V}$ & $\begin{array}{l}\text { Baik gadai maupun fidusia } \\
\text { memperhatikan kepentingan } \\
\text { kreditor, namun gadai } \\
\text { dianggap lebih optimal karena } \\
\text { objek dikuasai oleh pihak } \\
\text { ketiga yang disetujui yaitu PT. } \\
\text { KSEI (lebih aman) }\end{array}$ \\
\hline 2 & Mekanisme penjaminan & $\mathrm{v}$ & $\mathrm{X}$ & $\begin{array}{l}\text { Gadai saham tidak } \\
\text { memerlukan pendaftaran dan } \\
\text { cukup diserahkan kepada } \\
\text { kreditor atau pihak ketiga, } \\
\text { sehingga mudah, sederhana } \\
\text { dan cepat. }\end{array}$ \\
\hline 3 & Efisiensi perdagangan & $\mathrm{v}$ & $\mathrm{X}$ & $\begin{array}{l}\text { Tidak diperlukan biaya } \\
\text { pendaftaran, sehingga gadai } \\
\text { saham identik dengan efisien } \\
\text { (biaya rendah). }\end{array}$ \\
\hline 4 & $\begin{array}{l}\text { Kepatuhan terhadap prinsip } \\
\text { perdagangan di pasar modal }\end{array}$ & $\mathrm{v}$ & $\mathrm{X}$ & $\begin{array}{l}\text { Gadai memenuhi prinsip } \\
\text { wajar, teratur dan efisien. }\end{array}$ \\
\hline
\end{tabular}

Sumber : diolah oleh Penulis

Berdasarkan perbandingan antara gadai dan fidusia saham tanpa warkat di atas, maka praktik gadai saham tanpa warkat di pasar modal Indonesia lebih memberikan kepastian dan perlindungan hukum bagi kreditor dan memenuhi prinsip perdagangan di pasar modal.

Perkembangan regulasi terkait jaminan saham ini selanjutnya diatur dalam POJK No : 40/POJK.03/2017
Tentang Kredit atau Pembiayaan Kepada Perusahaan Efek dan Kredit Atau Pembiayaan dengan Agunan Saham. perubahan regulasi ini mempertimbangkan beberapa hal, yaitu :

1) memberikan kesempatan dan kemudahan bagi bank untuk mengembangkan usaha bank dengan berdasarkan pada asas perbankan yang sehat; 2) memungkinkan perkembangan pasar modal yang sehat melalui peran serta bank dalam pembiayaan kegiatan pasar 
modal dengan tetap memperhatikan prinsip kehati-hatian;

3) bahwa jaminan dalam pemberian kredit atau pembiayaan yang perlu harus diperhatikan yaitu keyakinan atas kemampuan dan kesanggupan debitor untuk melunasi kredit atau pembiayaan sesuai dengan yang diperjanjikan; 4) dalam menunjang perkembangan pasar modal, bank diperkenankan meminta agunan tambahan berupa saham untuk memperoleh keyakinan atas tersedianya jaminan pemberian krdit atau pembiayaan.

Berdasarkan POJK Agunan Saham ini jelas, bahwa saham tanpa warkat sebagai surat berharga dapat dijaminkan untuk memperoleh kredit atau pembiayaan sebagai agunan tambahan saja, yang tidak berkaitan langsung dengan objek yang dibiayai yang ditambahkan sebagai agunan apabila bank belu yakin atas kemampuan dan kesanggupan debitor untuk melunasi kredit atau pembiayaan sesuai dengan yang diperjanjikan. Berdasarkan POJK Tentang Agunan Saham saham yang telah terdaftar di Bursa Efek (saham scripless) dapat dijadikan agunan tambahan dengan beberapa persyaratan :

a. saham yang diagunkan tidak termasuk saham yang tidak mengalami transaksi dalam waktu 3 (tiga) bulan berturutturut sebelum akad kredit atau pembiayaan ditandatangani (Pasal 3 Ayat.2.a POJK) ; dan

b. harga saham yang akan dijadikan agunan bukan merupakan saham dengan harga pasar di bawah nilai nominal pada saat akad kredit atau pembiayaan ditandatangani (Pasal 3 Ayat 2.b POJK).

c. Nilai saham yang digunakan sebagai agunan tambahan kredit atau pembiayaan paling tinggi sebesar $50 \%$ dari harga pasar atau kurs saham yang bersangkutan di Bursa Efek pada saat akad kredit atau pembiayaan ditandatangani (Pasal 4 POJK)

Mengacu pada ketentuan dalam POJK Agunan Saham di atas, dapat disimpulkan bahwa saham tanpa warkat dapat digunakan sebagai agunan kredit atau pembiayaan dengan mempertimbangkan prinsip kehati-hatian bank.

Penjaminan Saham Tanpa Warkat Berdasarkan Prinsip Syariah

Selain gadai saham tanpa warkat berdasarkan ketentuan penjaminan konvesional, saat ini pasar modal menawarkan alternatif perdagangan dan efek syariah, sehingga terbuka peluang untuk penjaminan saham syariah yang diperdagangkan di Bursa Efek. Setidaknya ada 3 hal yang mendorong perkembangan 
pranata jaminan saham tanpa warkat berdasarkan prinsip syariah di pasar modal Indonesia.

a. Pasar Modal Indonesia telah menawarkan efek syariah, baik saham maupun instrumen lainnya seperti sukuk; unit penyertaan yang diterbitkan dalam rangka reksadana syariah; dan dana Investasi Real Estate Syariah berbentuk Kontrak Investasi Kolektif.

b. Landasan hukum tentang instrumen dan aktivitas pasar modal syariah sudah cukup kokoh. Saat ini terdapat 9 POJK yang mengatur tentang instrumen dan kegiatan berbasis prinsip syariah.

c. Pasar Modal Indonesia merupakan pasar modal pertama yang menawarkan sistem transaksi online syariah ( sharia online trading system/SOTS).

Berdasarkan perkembangan regulasi di pasar modal di atas, maka terdapat pilihan gadai saham tanpa warkat, yaitu gadai konvensional dan gadai syariah.

Gadai saham syariah mengacu pada pengaturan tentang pinjaman dengan menggadaikan barang sebagai jaminan utang (rahn) yang bersumber pada Fatwa yang dikeluarkan oleh Dewan Syariah Nasional-Majelis Ulama Indonesia (DSNMUI), yaitu :

a. Fatwa DSN-MUI No: 25/DSNMUI/III/2002 Tentang Rahn; b. Fatwa DSN-MUI No: 26/DSNMUI/III/2002 Tentang Rahn Emas;

c. Fatwa DSN-MUI No: 68/DSNMUI/III/2008 Tentang Rahn Tasjily.

d. Fatwa DSN-MUI No : 92/DSNMUI/2014 Tentang Pembiayaan yang disertai Rahn ( At-Tamwil Al-Mautsuq Bi Al-Rahn)

Berkenaan penjaminan saham tanpa warkat (scripless), maka yang dapat digunakan adalah Fatwa DSN-MUI No: 25/DSN-MUI/III/2002 Tentang Rahn dan Fatwa DSN-MUI No : 92/DSN-MUI/2014 Tentang Pembiayaan yang disertai Rahn ( At-Tamwil Al-Mautsuq Bi Al-Rahn). Penjaminan pada ke dua Fatwa tersebut tidak membedakan barang apakah barang bergerak atau tidak bergerak, sehingga objek rahn meliputi juga benda tidak bergerak. Dalam praktik, PT Pegadaian bahkan menggagas gadai syariah dengan objek sertifikat tanah dengan menggunakan rahn tasjily. ${ }^{27}$

Penggunaan gadai syariah untuk saham tanpa warkat, tentu harus memperhatikan kepatuhan terhadap prinsip syariah, termasuk objek gadainya yaitu saham. Saat ini Bursa Efek telah menyelenggarakan sistem online trading

27 Lastuti Abubakar \& Tri Handayani,(2017), Telaah Yuridis Perkembangan Regulasi Dan Usaha Pergadaian Sebagai Pranata Jaminan Kebendaan, Jurnal Bina Mulia Hukum, Vol.2.No.1, September,hlm. 87. 
syariah (sharia online trading system). Hal ini berarti pranata gadai saham tanpa warkat yang diperdagangkan di pasar modal dapat dilakukan baik melalui gadai saham konvensional maupun syariah.

\section{Penutup}

Berdasarkan pembahasan yang telah diuraikan dapat disimpulkan bahwa :

1. Saham tanpa warkat (scripless) dapat digunakan sebagai objek jaminan untuk memperoleh kredit atau pembiayaan. Berdasarkan POJK No : 40/POJK.03/2017 Tentang Kredit atau Pembiayaan Kepada Perusahaan Efek dan Kredit Atau Pembiayaan dengan Agunan Saham, saham tanpa warkat dapat digunakan sebagai agunan tambahan. Nilai saham yang digunakan sebagai agunan tambahan kredit atau pembiayaan paling tinggi sebesar $50 \%$ dari harga pasar atau kurs saham yang bersangkutan di Bursa Efek pada saat akad kredit atau pembiayaan ditandatangani (Pasal 4 POJK).

2. Pranata jaminan yang tepat bagi saham tanpa warkat yang diperdagangkan di Bursa Efek adalah gadai. Penguasaan saham tanpa warkat sebagai objek gadai oleh kreditor sebagai syarat sah nya gadai dapat dipenuhi dengan mendudukkan PT KSEI sebagai pihak ketiga yang disetujui untuk menguasai saham tanpa warkat dalam bentuk data elektronik. Selain itu, gadai saham tanpa warkat memenuhi tujuan untuk mencapai perdagangan yang teratur, wajar dan efisien, dengan tetap patuh pada prinsip kehati-hatian bank.

3. Pranata gadai saham dapat menggunakan regulasi gadai konvensional sebagaimana diatur dalam KUHPerdata maupun gadai syariah yang mengacu pada Fatwa DSN-MUI No: 25/DSN-MUI/III/2002 Tentang Rahn; dan Fatwa DSN-MUI No : 92/DSN-MUI/2014 Tentang Pembiayaan yang disertai Rahn ( AtTamwil Al-Mautsuq Bi Al-Rahn).

\section{E. Daftar Pustaka}

Buku

Lastuti Abubakar, (2009), Transaksi Derivatif $D i$ Indonesia-Tinjauan Hukum Tentang Perdagangan Derivatif Di Bursa Efek, Books Terrace \& Library, Bandung.

Neni Sri Imaniyati \& Panji Adam Agus Putra, ( 2017) , Hukum Bisnis Dilengkapi Dengan Kajian Hukum Bisnis Syariah, Refika Aditama, Bandung.

Otoritas Jasa Keuangan, (2016) , Perbankan-Seri Literasi Perguruan Tinggi-Seri 2, Jakarta. 
Otoritas Jasa Keuangan, Laporan Kinerja Otoritas Jasa Keuangan 2012-2017, Jakarta.

Sri Soedewi Maschoen Sofwan, (2000), Hukum Perdata : Hukum Benda, Liberty, Yogyakarta

Jurnal

Hendra Halwani dalam Herlan Firmansyah \& Endang Hendra, (2015), Implikasi Globalisasi Ekonomi Dan Perdagangan Bebas terhadap Stabilitas Nilai Rupiah, Jurnal AsySyariah Vol.17 No. 1.

Lastuti Abubakar, (2015), Telaah Yuridis Perkembangan lembaga dan Objek Jaminan Gagasan Pembaruan Hukum Jaminan Nasional), Buletin Hukum Kebansentralan, Bank Indonesia, Vol. 12, No.1.

Lastuti Abubakar \& Tri Handayani, (2017), Telaah Yuridis Perkembangan Regulasi Dan Usaha Pergadaian Sebagai Pranata Jaminan Kebendaan, Jurnal Bina Mulia Hukum, Vol.2.No.1, September 2017.

Najeb MH Masoud, (2013), The Impact of Stock Market Performance Upon Economic Growth, International
Journal of Economic and Financial Issues,Vol.3,No.4, https://www.econjournals.com/index .php/ijefi/article/viewFile/557/pdf

Peraturan perundang-undangan

Fatwa DSN-MUI No: 25/DSNMUI/III/2002 Tentang Rahn;

Fatwa DSN-MUI No: 26/DSNMUI/III/2002 Tentang Rahn Emas;

Fatwa DSN-MUI No: 68/DSNMUI/III/2008 Tentang Rahn Tasjily. Fatwa DSN-MUI No : 92/DSN-MUI/2014 Tentang Pembiayaan yang disertai Rahn ( At-Tamwil Al-Mautsuq Bi AlRahn)

Kitab Undang-undang Hukum Perdata. Undang-Undang No : ..Tentang Perbankan Undang-undang No : ..Tentang Perbankan Syariah.

Peraturan Pemerintah yang dimaksud adalah PP Nomor : 45 Tahun 1995 Tentang Penyelenggaraan Kegiatan di Bidang Pasar Modal

Peraturan Bursa Efek No. II-A Tentang Perdagangan Efek Bersifat Ekuitas. Keputusan Direksi Bursa Efek Indonesia No :Kep-00399/BEI/11-2012 yang diubah dengan Keputusan Direksi PT Bursa Efek Indonesia No : Kep00071/BEI/11-2017 